\title{
The December 2008 Crammont rock avalanche, Mont Blanc massif area, Italy
}

\author{
P. Deline ${ }^{1}$, W. Alberto ${ }^{2}$, M. Broccolato ${ }^{3}$, O. Hungr ${ }^{4}$, J. Noetzli ${ }^{5}$, L. Ravanel ${ }^{1}$, and A. Tamburini ${ }^{2}$ \\ ${ }^{1}$ EDYTEM Lab, Université de Savoie, CNRS, Le Bourget-du-Lac, France \\ ${ }^{2}$ Imageo S.r.l., Torino, Italy \\ ${ }^{3}$ Servizio Geologico della Regione Autonoma Valle d'Aosta, Quart, Italy \\ ${ }^{4}$ Department of Earth and Ocean Sciences, University of British Columbia, Vancouver, Canada \\ ${ }^{5}$ Glaciology, Geomorphodynamics \& Geochronology, University of Zurich, Zurich, Switzerland
}

Received: 28 April 2011 - Revised: 30 September 2011 - Accepted: 26 October 2011 - Published: 15 December 2011

\begin{abstract}
We describe a $0.5 \mathrm{Mm}^{3}$ rock avalanche that occurred in 2008 in the western Alps and discuss possible roles of controlling factors in the context of current climate change. The source is located between $2410 \mathrm{~m}$ and $2653 \mathrm{~m}$ a.s.l. on Mont Crammont and is controlled by a densely fractured rock structure. The main part of the collapsed rock mass deposited at the foot of the rock wall. A smaller part travelled much farther, reaching horizontal and vertical travel distances of $3050 \mathrm{~m}$ and $1560 \mathrm{~m}$, respectively. The mobility of the rock mass was enhanced by channelization and snow. The rock-avalanche volume was calculated by comparison of pre- and post-event DTMs, and geomechanical characterization of the detachment zone was extracted from LiDAR point cloud processing. Back analysis of the rock-avalanche runout suggests a two stage event.

There was no previous rock avalanche activity from the Mont Crammont ridge during the Holocene. The 2008 rock avalanche may have resulted from permafrost degradation in the steep rock wall, as suggested by seepage water in the scar after the collapse in spite of negative air temperatures, and modelling of rock temperatures that indicate warm permafrost $\left(T>-2^{\circ} \mathrm{C}\right)$.
\end{abstract}

\section{Introduction}

Rockfall is a typical hazard in high mountain areas due to steep slopes, high relief, intense rock fracturing, seismicity, paraglacial control, periglacial processes, and the presence and interaction of snow, glaciers, and permafrost. Ice and/or snow on the ground surface enhances the mobility of rockfall because of a lower coefficient of friction, increased

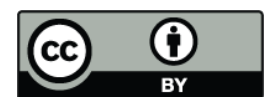

Correspondence to: P. Deline (pdeli@univ-savoie.fr) ground saturation, and the incorporation of ice and snow into the moving rock mass (Evans and Clague, 1988; Deline, 2009; Schneider, 2011). In inhabited mountain valleys, rock avalanching (the extremely rapid flow movement of fragmenting rock particles) represents a potential high risk for increasing infrastructure and population, as recently shown at Kolka-Karmadon, Caucasus (Huggel et al., 2005). Present glacier shrinkage (Zemp et al., 2007) and permafrost degradation in steep rock walls in the context of current global climate change may change hazard zones, modify controlling processes and increase the frequency and magnitude of rockfalls and rock avalanches (Ballantyne, 2002; Fischer et al., 2006; Gruber and Haeberli, 2007; Ravanel and Deline, 2010).

Recent examples of rockfalls and rock avalanches in the Mont Blanc massif (western European Alps), range from $10000 \mathrm{~m}^{3}$ to $2 \times 10^{6} \mathrm{~m}^{3}$ in volume (Deline, 2009) and include the small rockfalls at the Tour des Grandes Jorasses in May 2002 and September 2007, the larger Tré-la-Tête rockfall in September 2008 (Deline et al., 2008), the small Drus rock avalanche in June 2005 (Ravanel and Deline, 2008), and the large Brenva rock avalanche in January 1997 (Deline, 2001).

The purpose of this paper is to document the rock avalanche that detached from Mont Crammont (2749 m a.s.l.) in the Mont Blanc massif area in December 2008 (Fig. 1), and to investigate and discuss its possible controlling factors.

\section{Geological setting of Mont Crammont}

Mont Crammont rises $1700 \mathrm{~m}$ above the Doire Baltée river (Fig. 2), which drains the Valley of Aosta (Fig. 1). Located $10 \mathrm{~km}$ south-east from Mont Blanc, in the Berrio Blanc massif (Fig. 1), it is composed of the so-called "Flysch de Tarentaise" Sequence (FTS, upper Cretaceous) of the

Published by Copernicus Publications on behalf of the European Geosciences Union. 


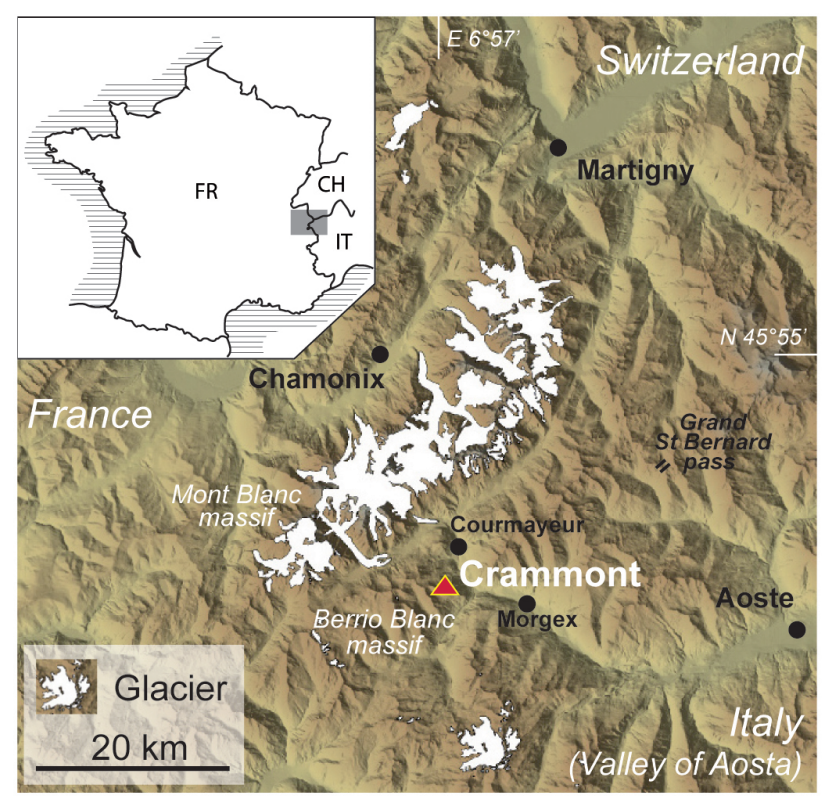

Fig. 1. Location of the study area. Glaciers from Corine Land Cover 2000 (Swiss glaciers only represented in the Mont Blanc massif).

Valais geological zone (Antoine, 1972). The FTS is bounded to the north by the Frontal Pennic Thrust, the contact between Internal and External Alpine Zones; it is up to 1000$\mathrm{m}$ thick and has two main formations: (1) the Basal Formation $(\mathrm{BF})$, composed of massive beds of conglomerate (abundant dolomitic and calcareous elements, calcareous cement) without schistose interbedding; and (2) the "Flysch de Tarentaise" Formation, the upper level up to 800-m-thick, composed of alternate beds of limestones (sandy and not), calcareous and phyllitic schists (calcschists), and molassic sandstones. Dip and dip direction of the FTS beds (i.e. schistosity) are ca. $50^{\circ}$ and $\mathrm{N} 150^{\circ} \mathrm{E}$, respectively.

The rock avalanche fell from the north face of the rock ridge that joins the Tête de l'Âne and Mont Crammont (Fig. 3). This anaclinal north slope is a normal escarpment roughly perpendicular to the dip of the bedding plane. It culminates at $2653 \mathrm{~m}$ a.s.l. in the detachment area, with a mean slope angle of $50^{\circ}$, and rises $400-550 \mathrm{~m}$ above a $100-150$ m-high scree slope.

\section{Characteristics of the 2008 rock avalanche}

\subsection{Chronology of the event}

On 24 December 2008, at ca. 17:21 local time (LT), a small rock avalanche detached from the north face of the Crammont ridge (Fig. 4). The collapse was preceded by several mixed rock-snow avalanches during the early afternoon (M. Pellin, personal communication, 2009), and small rockfalls detached from several points around a rock spur (e.g.

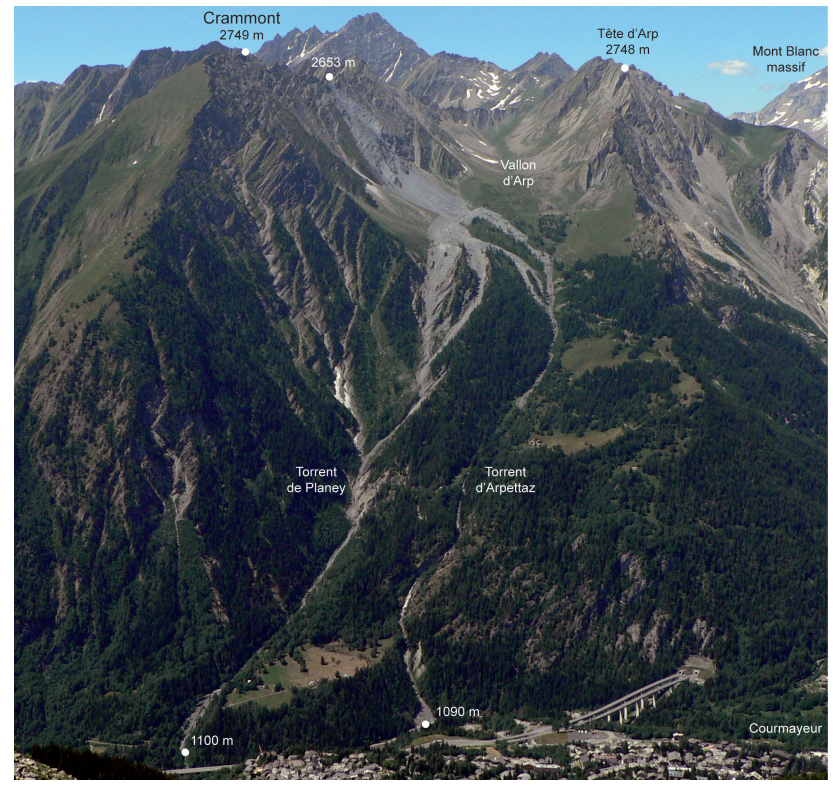

Fig. 2. General view of the Berrio Blanc massif from NE (July 2009), with used toponymy. Source zone scar and main deposit (light grey) of the Crammont rock avalanche are in the top center; secondary deposit in the two narrow torrent streams down to the Doire River. Note highway and village at the foot of the opposite side of the Doire valley.

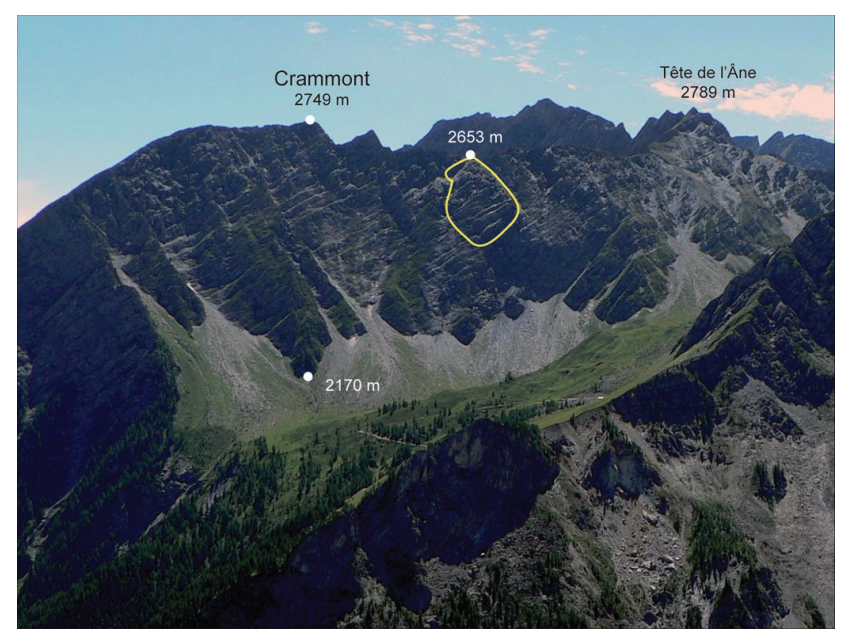

Fig. 3. View of the Crammont north side (August 2008). Area that eventually collapsed is delimited in yellow.

at 17:01 LT: S. Roveyaz, personal communication, 2010), possibly in pre-existing couloirs. A larger rockfall detached from the base of a spur in the middle of the north face at ca. 2400-2450 m a.s.1. (Fig. 4). Two minutes later, the whole spur collapsed (Fig. 4) and released a rock avalanche and a dense black dust cloud, which travelled across the Vallon d'Arp, brushed against the base of the Tête d'Arp, and entered the Doire valley. Following the topography, the rock 

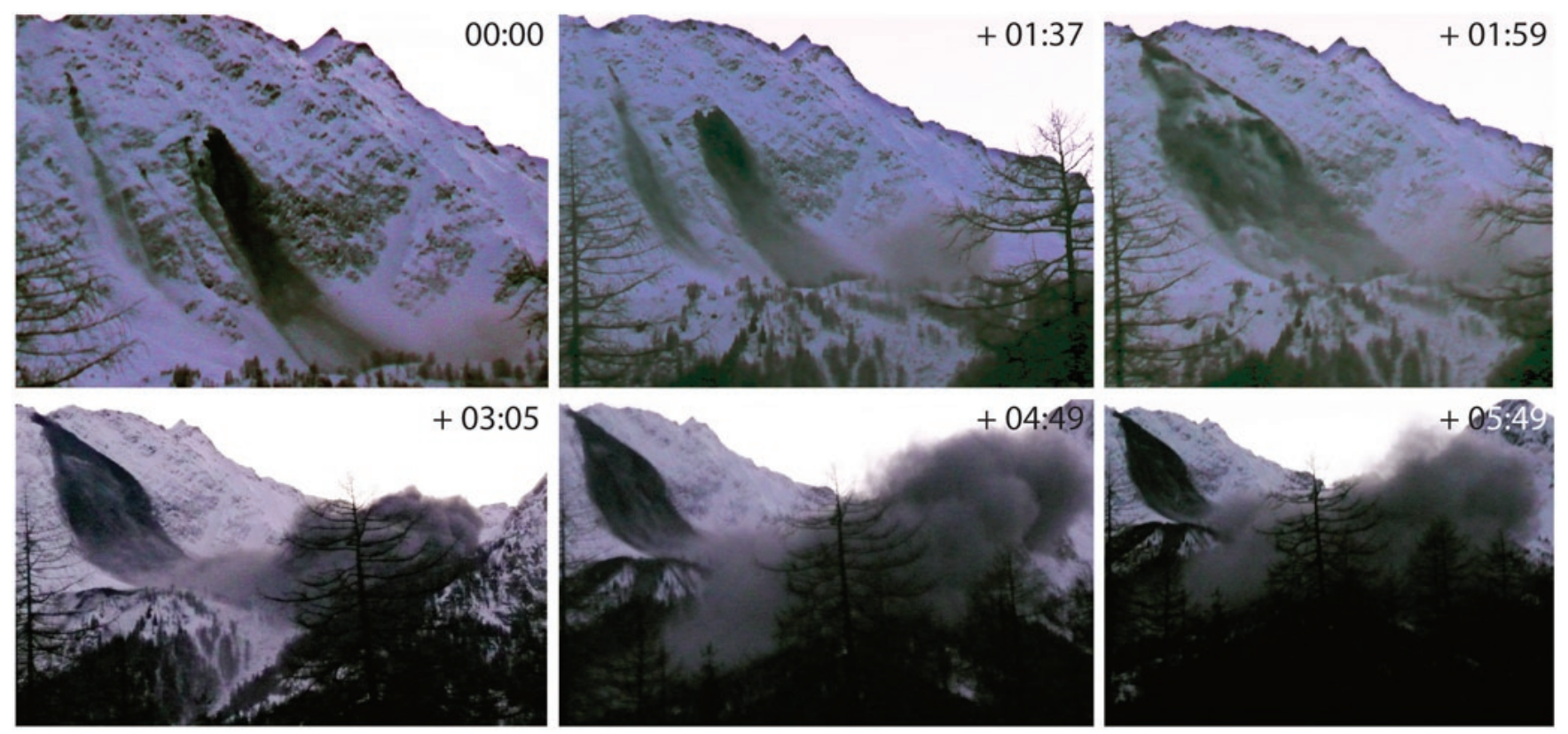

Fig. 4. Photographic sequence of the rock avalanche on the 24 December 2008 (E. Zerga). Time in mm:ss; 00:00 corresponds to ca. 17:21 (local time).

avalanche divided into two west and east arms and crossed the snow-covered plateau between 2050 and $2150 \mathrm{~m}$ a.s.l., where it deposited the bulk of the rock mass (Fig. 5a and b). A small part of the mass continued downstream, again forming two north and south branches channelled by the gullies of the Torrents d'Arpettaz and de Planey. The north Arpettaz branch, which mainly contained snow (Fig. 5c and d), reached the Doire river at 1090 m a.s.l. without damming it; rock debris material was more abundant in the south Planey branch, which does not reach the river.

Vertical and horizontal travel distances were 1560 and $3050 \mathrm{~m}$ (Fig. 6). This corresponds to an apparent coefficient of internal friction $H / L=0.51$, and a runout travel angle of $27.1^{\circ}$. Using the photographic sequence (Fig. 4), the estimated mean velocity of the rock-avalanche front during the first minute, i.e. from the base of the detachment zone to the head of the Torrent de Planey, was $14.5 \mathrm{~m} \mathrm{~s}^{-1}$. The mean velocity of the dust cloud was $16.5 \mathrm{~m} \mathrm{~s}^{-1}$ during this first phase and decreased to $7.7 \mathrm{~m} \mathrm{~s}^{-1}$ during the next $100 \mathrm{~s}$.

Water seepage was observed in the Crammont scar in the days after the collapse. Rockfalls were observed continuously during the following months, caused by sliding and toppling of a large amount of rock debris and snow accumulated on the gentler bottom slope of the scar (Fig. 7), enhanced in spring by snowmelt and rain runoff.

\subsection{The failure and deposition zones}

The scar ranges from 2400 to $2653 \mathrm{~m}$ a.s.l., with maximum widths and depths of $160 \mathrm{~m}$ and $53 \mathrm{~m}$, respectively (Fig. 8), and the collapsed volume is $535000 \mathrm{~m}^{3} \pm 30000 \mathrm{~m}^{3}$. This data was obtained by comparing the $2 \mathrm{~m}$ resolution DEM of the Valley of Aosta Region generated from airborne $\mathrm{Li}$ DAR before December 2008 and a high resolution $(20 \mathrm{~cm})$ DEM of the Crammont area generated in June 2009 from helicopter-borne LiDAR - both DEMs were obtained by resampling the respective point clouds on a common grid of $2 \mathrm{~m} \times 2 \mathrm{~m}$. The landslide volume was calculated both in the detachment and accumulation zones (Fig. 8). Two different methods were used in both estimations: the first in a 2.5D GIS environment by subtracting the two DEMs with ESRI ArcGIS Spatial Analyst (Giardino et al., 2005); the second in a 3-D environment with InnovMetric Polyworks after creating a triangulated mesh for each point cloud and computing the volume included between the two surfaces (Broccolato et al., 2006). Due to the absence of hanging or very steep slopes, both methods could be successfully applied; the results show a slight difference of a few thousand cubic meters. The ratio between the computed volumes in the detachment and accumulation areas is about 1.3 - a minimal ratio, as the deposits in the two gullies are not taken into account.

A large amount (possibly as much as $50 \%$ ) of the December deposit material was snow (Fig. 5). We will describe here the rock deposit that remained on the ground in late spring 2009, after the melting of the embedded snow and the 


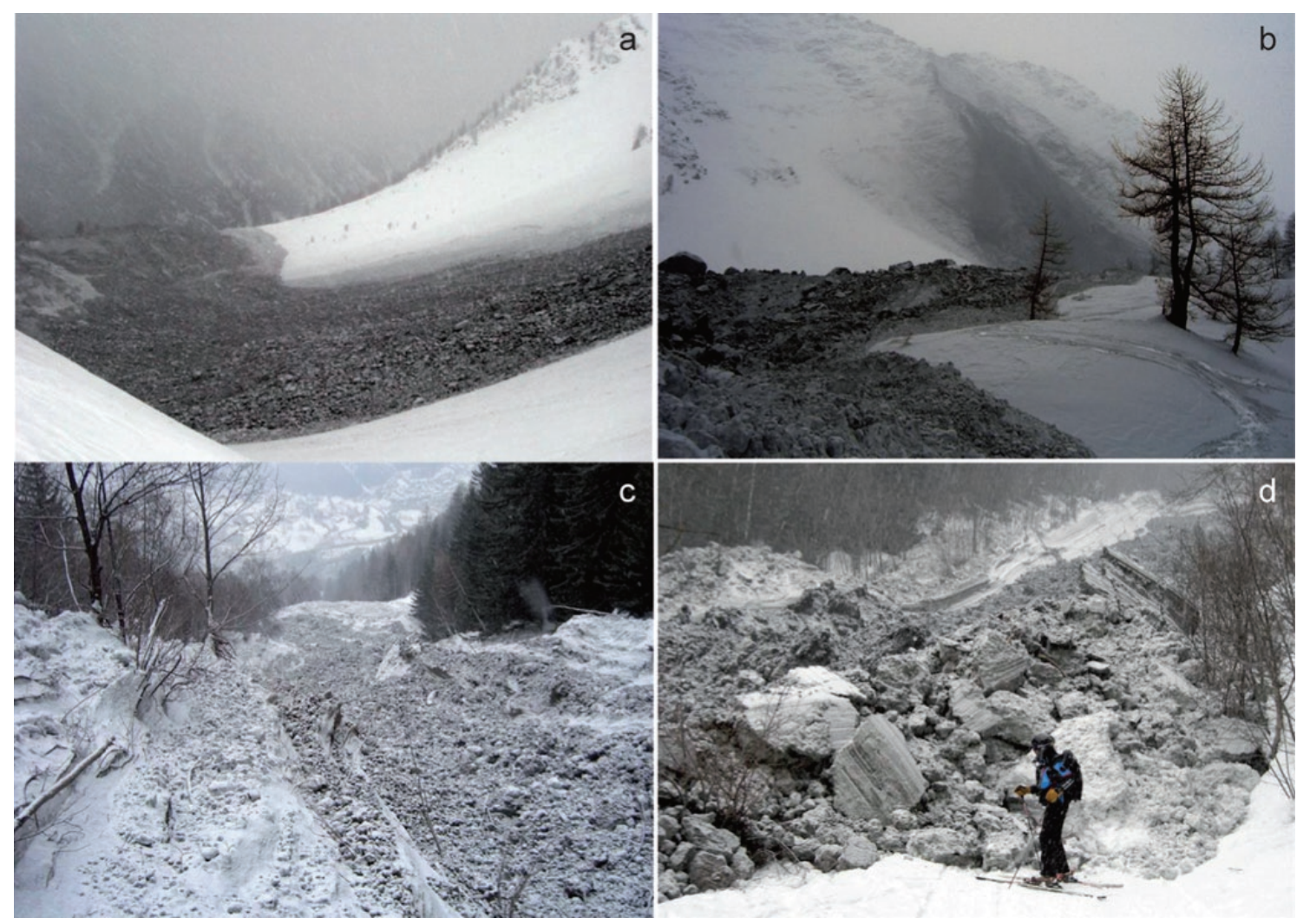

Fig. 5. Snow and rock deposit of the rock avalanche at different elevations (25 December 2008, G. Grange). (a) 2050-2250 ma.s.1.; (b) $2050 \mathrm{~m}$; (c) $1500 \mathrm{~m}$; (d) $1150 \mathrm{~m}$.

pre-event snow cover - a part of which was still preserved below the deposit in some areas. The bulk of the collapsed rock mass was found on the scree slope (2150-2250 m a.s.1.) and on the plateau (2050-2150 ma.s.l.). It is possible that a large part of the deposit on the scree slope was created by the secondary falls. The rock deposits generally show sharp limits, have longitudinal ridges, contain mainly coarse debris, and are inversely graded, openwork and clast-supported with an abundant matrix. Their thickness is variable:

- The main rock deposit (4a in Fig. 6) is generally $>0.60$ to $1 \mathrm{~m}$ thick, reaching some meters in the largest boulder (a-axis $>2 \mathrm{~m}$ ) areas (Fig. 9a); the thickness of the deposit is very non-uniform, due to both pre-event topography and depressions resulting from snow melt $(>1 \mathrm{~m}$ deep in thicker deposit).

- Meter-wide splash areas (4b in Fig. 6) formed adjacent to the margins of the deposit in several places, $2-5 \mathrm{~cm}$ up to $10 \mathrm{~cm}$ thick. Generally, silts and sands are dominant, with a variable proportion of decimetric debris. However, some splash areas are composed of coarser debris (gravels to cobbles) without fine material. On the scree slope, three boulders a few metres in size were thrown out of the deposit.
- The vegetation and the soil surface of some areas within the landslide area are scoured without any rock deposit (Fig. 9b), especially on steeper slopes with alpine meadow and shrubs (4c in Fig. 6).

- Finally, an extended thin $(<1 \mathrm{~mm})$ silt deposit on top of the snow cover resulted from the dust cloud covering the Vallon d'Arp, which was redistributed by the snow melt runoff in spring 2009.

In the torrent gullies, the average final rock deposit is thinner than on the plateau. It ranges from several decimetres to a few metres in many areas, with a mean minimum thickness of ca. $20 \mathrm{~cm}$ (e.g. in the distal part of the Arpettaz branch). Unsorted large clasts are matrix-supported. The gradation suggests an increase of the matrix production by dynamic fragmentation from proximal (clast-supported fabric) to distal (matrix-supported fabric) deposition areas.

\section{Factors controlling slope stability}

\subsection{Low frequency of rockfalls during the Holocene}

Reconstruction of the glacier extension of the Last Glacial Maximum in the Mont Blanc area suggests that the trim 


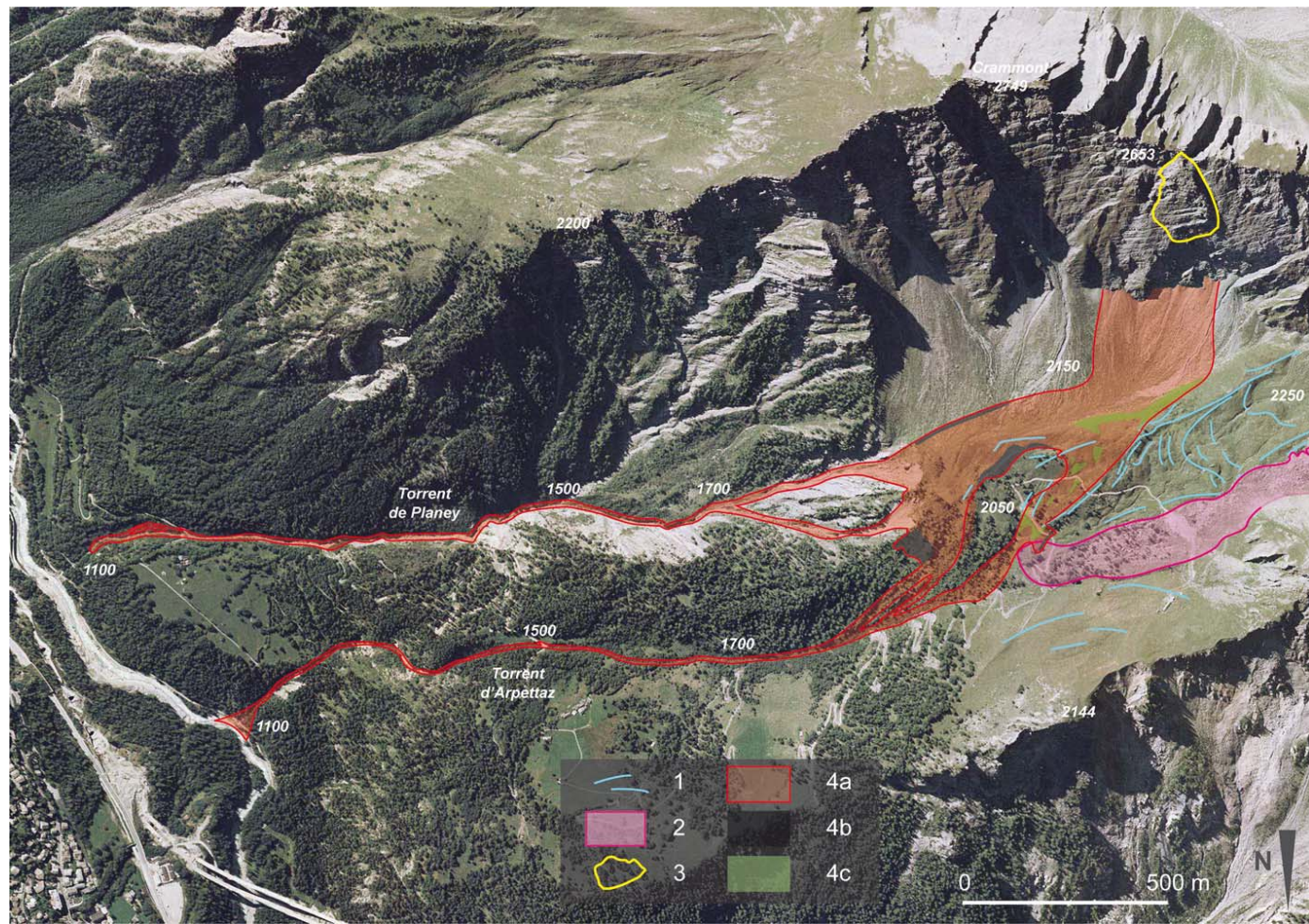

Fig. 6. Map of the Crammont area, with main geomophological elements. 1: Lateglacial moraines; 2: old rock-avalanche deposit; 3: 2008 rock-avalanche source zone; 4: 2008 rock-avalanche deposit (4a: rock deposit; 4b: scoured area; 4c: splash area). Elevations are in m a.s.l.; 2008 orthophoto.

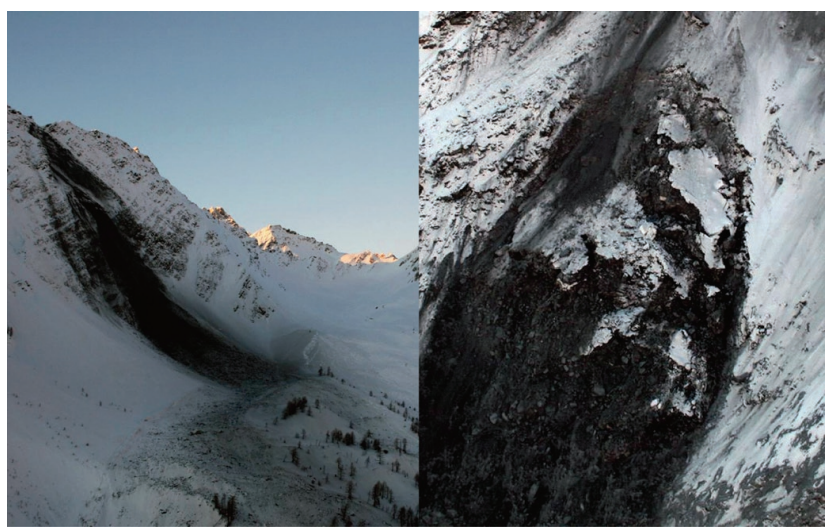

Fig. 7. North side of the Crammont (left) and detailed view (right) of the thick rock debris accumulation in the gentler bottom area of the rock-avalanche scar (13 January 2009).

line on the north side of Crammont was located between ca. $2600 \mathrm{~m}$ a.s.l. (Coutterand and Buoncristiani, 2006) and slightly above $2700 \mathrm{~m}$ a.s.l. (Porter and Orombelli, 1982). Thus, rock slope failures due to glacial downwasting and consequent debuttressing have affected the Crammont side during the paraglacial time (Ballantyne, 2002) which ended before the Lateglacial termination, as shown by the preservation of the Lateglacial morainic complex of the Vallon d'Arp
(1 in Fig. 6). The shape of the north side suggests indeed that large collapses occurred before this termination, which probably deposited onto the surface of the downwasting glacier.

During the Holocene, the main active processes were frostshattering due to freeze-thaw cycles, and debris and boulder falls, as shown by the large scree slope at the foot of the north side of the Crammont. Partly vegetated, it is reshaped by small debris flows in summer and wet snow avalanches in spring.

No large Holocene rockfall deposits dating from before 2008 could be observed in the Vallon de l'Arp, except one composed of BF rocks (2 in Fig. 6) detached from the south face of the Tête d'Arp (Fig. 2); soil and forest covering the deposit and weathering of its boulders suggest that this Holocene rockfall is at least several centuries old.

These observations can be extrapolated to the Berrio Blanc massif: extended scree slopes at the foot of its scarps and several presently active rock glaciers with boulders of decimetre size illustrate how the stratigraphy and high fracturing density of the FTS make this massif prone to seasonal frost action during the Holocene. Large rockfalls occurred with very low frequency in this massif, in contrast to the near-by Mont Blanc massif, where small and large rock avalanches occurred frequently (Orombelli and Porter, 1981; Deline, 2009). 


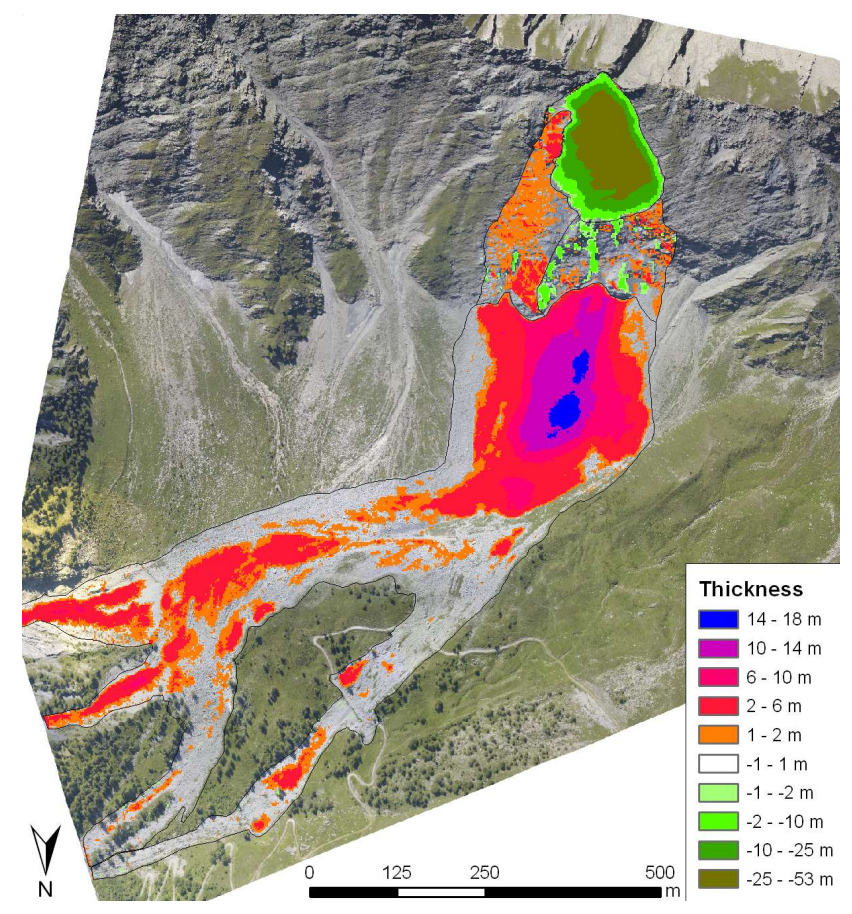

Fig. 8. Thickness map of the detachment and accumulation zones obtained after subtraction of 2009 from 2008 LiDAR DEM; thickness values are in meters.

According to SisFrance (national database of historical seismicity of France), four earthquakes of weak to moderate intensity have affected the Mont Blanc area of in the decade that preceded the 2008 collapse, with epicenters at Magland (France, 19 August 2000), Martigny (Switzerland, 23 February 2001), Petit-Saint-Bernard (Italy, 12 June 2004) and Vallorcine (France, 8 September 2005). Archives of the INGV (Istituto Nazionale di Geofisica e Vulcanologia, Italy) mention three earthquakes with a local magnitude $\left(M_{1}\right) \geq 2$ in the Aosta Valley in 2008, with epicenters at Nus (14 September, $M_{1}: 2.0 ; 23$ October, $\left.M_{1}: 2.9\right)$ and Pré-Saint-Didier (11 November, $M_{1}: 2.7$ ), $\sim 60$ and $\sim 8 \mathrm{~km}$ far from the Crammont, respectively. This last earthquake could have contributed to prepare the 24 December collapse, but no triggering seismic event was recorded during the failure itself.

\subsection{Geological discontinuities in the Crammont detachement area}

Both the rock face and boulders in the deposit show a high fracture density. The ridge summit, which seems to be double-crested in some sections, presents open, vertical cracks. Many fractures are filled with quartz and calcite, while reddish rock coating indicates past hydrothermal circulation or near-surface weathering due to redox processes (limonite).

A geomechanical characterization of the rock slope was carried out starting from the helicopter-borne LiDAR point cloud. A semi-automatic tool based on the macro language of InnovMetric Polyworks enabled the calculation of dip and dip-direction for over 300 discontinuity surfaces (Broccolato et al., 2006). Seven major discontinuity sets have been recognized within an area of about $1 \mathrm{~km}^{2}$, of which four sets likely determined the failure (Fig. 10). A rotational slide probably occurred along a slightly curved surface formed by the combination of two surfaces belonging to Set 4 and Set 5 , while steeper discontinuity sets acted as upper and lateral release surfaces. A kinematic analysis (Hoek and Bray, 1981) carried out in order to better understand the potential sliding mechanisms showed that planar sliding is feasible both for Set 4 and Set 5 with an average slope orientation of $48 / 14$ (dip/dip direction) measured in the detachment area on the pre-failure LiDAR point cloud.

\subsection{Meteorological conditions prior to the event}

Precipitation amounted to 99.2 and $0 \mathrm{~mm}$ at Morgex (938 m a.s.1.; $7.5 \mathrm{~km}$ east of Crammont) during the periods 1-17 December and 18-24 December 2008, respectively. At Grand-Saint Bernard Pass ( 2472 ma.s.l.; 22 km northeast of Crammont), mean daily air temperature (MDAT) increased regularly from $-13.1^{\circ} \mathrm{C}$ to $-1{ }^{\circ} \mathrm{C}$ during the period 25 November-24 December 2008, before dropping to $-13.6^{\circ} \mathrm{C}$ on 28 December 2008 (Fig. 11). MDAT became higher than 1960-2007 average after 14 December, but it remained below $0{ }^{\circ} \mathrm{C}$ (Fig. 11); maximum daily air temperature was $>0{ }^{\circ} \mathrm{C}$ during four days of the period: $18\left(1.4^{\circ} \mathrm{C}\right)$, $22\left(1.1^{\circ} \mathrm{C}\right), 23\left(1.0^{\circ} \mathrm{C}\right)$, and 24 December $\left(2.1^{\circ} \mathrm{C}\right)$.

\subsection{Permafrost conditions}

In order to asses permafrost conditions in the starting zone we have to rely on reasonable estimates using established models because the subsurface phenomenon is invisible and no local data is available. For this, we sketch a schematic model of the temperature in a $\mathrm{N}-\mathrm{S}$ cross section through the summit ridge of the Crammont, assuming lateral variability of subsurface temperature being much smaller along the ridge than across the ridge. The simulation is based on the approach by Noetzli (2008), which has been tested and applied (e.g. Noetzli et al., 2008; Noetzli and Gruber, 2009; Noetzli et al., 2010) for modelling 3-D temperature distribution in steep alpine terrain. The rock surface temperatures were estimated along the cross section profile based on the results from a distributed energy balance model (Noetzli and Gruber, 2009) and respective elevation, aspect and slope, and for idealized conditions in near-vertical rock that does not retain a thicker snow cover. The subsurface temperature field was then calculated based on heat transport by conduction using the surface temperatures as upper boundary condition within the modelling package COMSOL Multiphysics (Software by Femlab AG). The subsurface model includes a homogeneous isotropic subsurface. The effect of latent heat is 

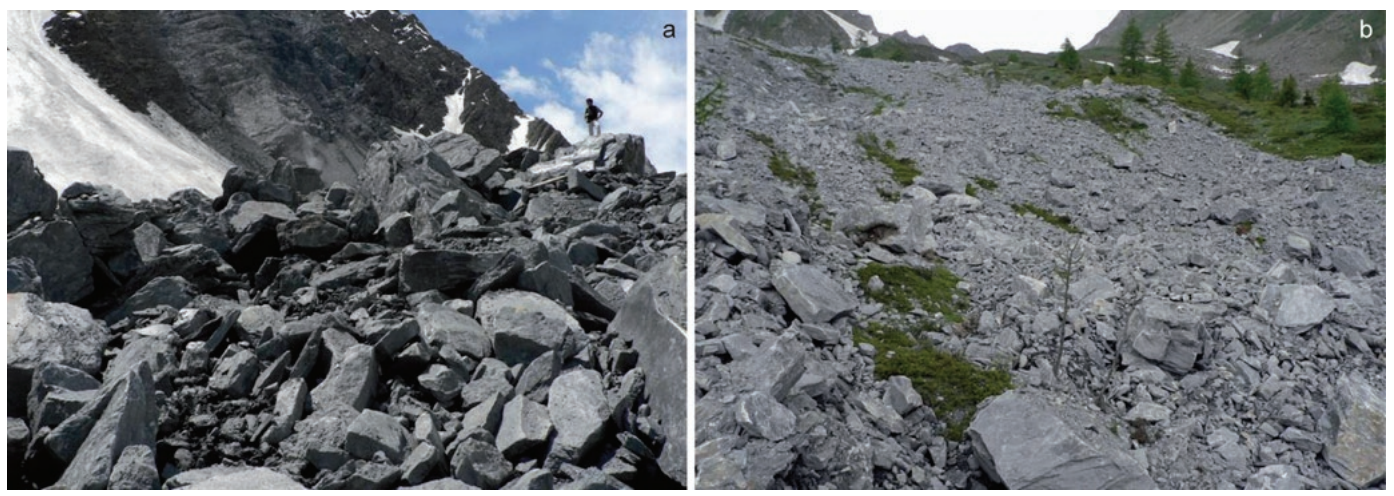

Fig. 9. Final rock deposit of the rock avalanche on the plateau, after the melting of the snow (June 2009). (a) several-m-thick deposit in the lower centre of the east arm; (b) scoured areas in the west arm.
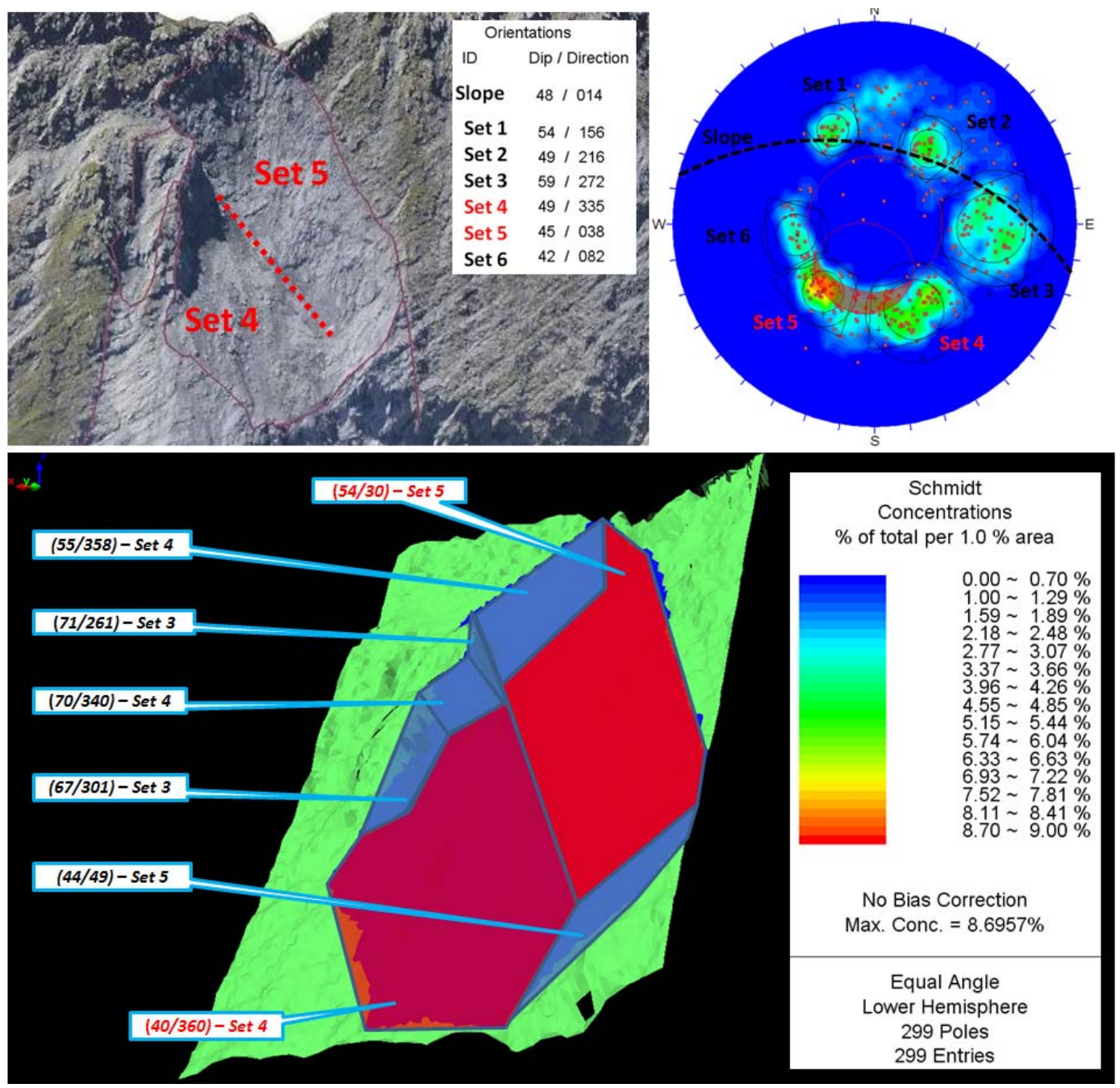

Fig. 10. View of the rock-avalanche detachment area (above, left) and 3-D schematic representation of the 4 main discontinuity sets which probably controlled the landslide (below; dip direction/dip are in degrees). Above right: stereoplot (Equal Area, Lower Hemisphere), with the poles of the 7 main discontinuity sets identified in the study area after processing the LiDAR point cloud; dashed black line: local orientation of the slope before the landslide occurrence (48/18); red area: planar sliding zone; set 1: schistosity; a friction angle of $37^{\circ}$ was assumed for the kinematic analysis. 


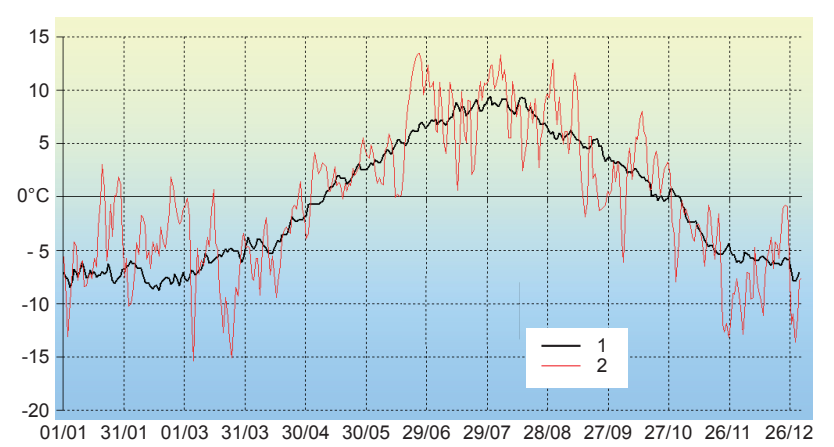

Fig. 11. Air temperature at Grand St Bernard pass (2472 m a.s.l.; data from MeteoSwiss). 1: 1960-2007 average of the mean daily air temperature; 2: 2008 mean daily air temperature.

not included. For details on the modelling procedure, sensitivity studies, and validation we refer to Noetzli (2008).

The basis for the estimation of rock surface temperatures are simulations using the climate time series from the Swiss station Corvatsch $(3330 \mathrm{~m}$ a.s.l.; $235 \mathrm{~km}$ east-north-east of Crammont; data source: MeteoSwiss), where continuous data of all required parameters are available. The climatic conditions at high elevations in the Crammont area are assumed to be similar to those for the inner alpine conditions in the Engadine, because of the mountain effect of the Mont Blanc massif in the west (see also leading climatologic regions of the greater alpine region by Auer et al., 2007). Further, the horizontal extrapolation of climate variables between climate stations at high elevation has been shown to lead to significantly smaller differences even for large distances compared to vertical extrapolation of stations nearby (e.g. Auer et al., 2007; Suter, 2002).

For the 3-dimensional subsurface heat conduction, we created a mesh describing the cross section, with increasing mesh size towards the surface and a lower boundary heat flux of $0.08 \mathrm{Wm}^{-2}$ at sea level. Subsurface properties were assumed to be homogeneous for the entire cross section and set to values taken from literature (i.e. heat capacity 2 $10^{6} \mathrm{~J} \mathrm{~m}^{-3} \mathrm{~K}^{-1}$ and thermal conductivity $2.5 \mathrm{~W} \mathrm{~K}^{-1} \mathrm{~m}^{-1}$, cf. Noetzli, 2008). Because the current subsurface thermal field is in a transient state mainly due to the recent 20th century warming, we assumed a temperature increase of $+2{ }^{\circ} \mathrm{C}$ since the end of the LIA (cf. Noetzli et al., 2008) and initialized the temperature field for $150 \mathrm{yr}$. Effects from earlier climate variations are assumed to be negligible for the depth scales considered here (Noetzli and Gruber, 2009). The idealized and simplified assumptions in the model (e.g. no snow cover, heat transport by conduction only, a homogeneous subsurface, no effects of latent heat) allow us to draw a schematic picture of the temperature range and conditions in the Crammont ridge. Sensitivity studies (Noetzli and Gruber, 2009) have shown that the general pattern is not strongly affected by these assumptions. New studies on bedrock permafrost

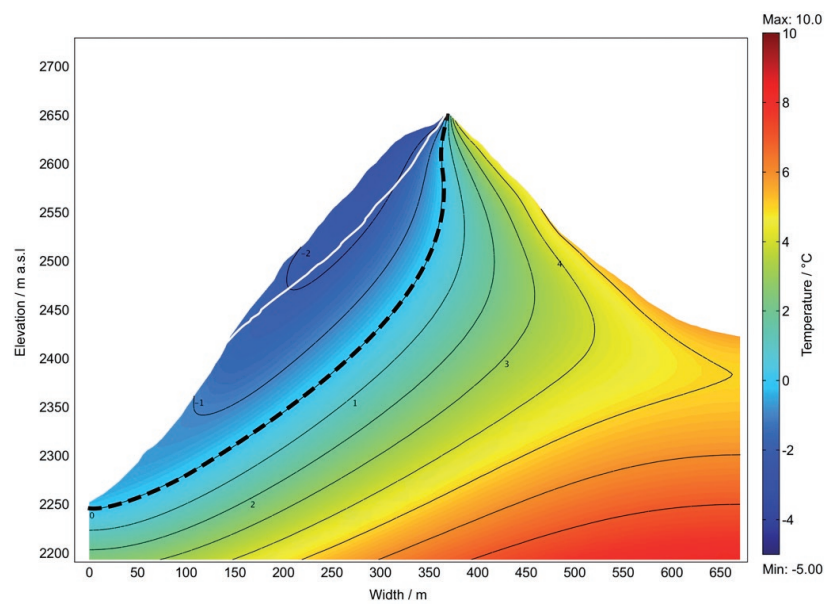

Fig. 12. Simulated subsurface temperature field in the Crammont rock ridge (topography prior to the 2008 rock failure). Black dashed line: $0^{\circ} \mathrm{C}$ isotherm; white line: detachment zone (i.e. post-failure topography, based on 2009 DTM).

temperatures point to colder conditions at depth than at the surface in rock where a thin snow cover is accumulated or cold air convection takes place in clefts (Hasler et al., 2011; Pogliotti, 2011). The simulations do not intend to represent accurate ground temperatures, but to illustrate the general pattern and range of the subsurface thermal field in the detachment area. Currently, no field temperature data for model validation is available.

The resulting schematic subsurface temperature field is displayed in Fig. 12, where also the schematic permafrost boundary is illustrated by the $0^{\circ} \mathrm{C}$ isotherm. The general temperature pattern is typical for a west-east trending ridge situation with near-vertical isotherms in the uppermost part and temperatures changing mainly with their position between the different warm mountain sides. In the summit ridge of Mont Crammont, the modeled schema suggests that permafrost may be present on the north slope with lowest temperatures of around $-3^{\circ} \mathrm{C}$ in the highest parts, but mainly in the range above $-2{ }^{\circ} \mathrm{C}$. The south side is potentially free of permafrost and the permafrost boundary would then be nearly vertical within the summit ridge of Mont Crammont. The recent 20th century warming has likely affected the uppermost ca. $50 \mathrm{~m}$ below the surface as can be seen from the isotherms which are strongly bent towards the surface.

Our modelling suggests that warm permafrost may be present today in the north face. During the Neoglacial (i.e. the colder second half of the Holocene; Wanner et al., 2008; Ivy-Ochs et al., 2009), the temperature in the rock wall was lower than today and since the end of the LIA, the climate has been warming. For about the past decade air temperatures have constantly been considerably above the long-term average (e.g. www.meteoswiss.ch), potentially they were even higher than earlier during the Holocene. The increasing air 
temperatures may have progressively degraded permafrost in the mountain areas. The role of permafrost degradation for rock stability has often been discussed in recent literature. The processes and mechanisms involved are not yet fully clear, but theoretical (e.g. Gruber and Haeberli, 2007; Hasler, 2011), experimental (Hasler et al., 2011), and statistical (Ravanel et al., 2010; Fischer et al., 2011) studies suggest its likely contribution, and point to an increase in rockfall events - especially in the past one-two decades - and an increased sensitivity of warm permafrost areas. Permafrost degradation is only one of the factors reducing the stability of a rockwall and is never the only cause. However, of the potential contributing factors, permafrost can be seen as the one undergoing the largest and fastest changes today and in the recent decades, while other factors such as geology and topography are constant over longer time periods. Further, Hasler (2011) states that conduction-driven failures can occur throughout the year because they are related to warming permafrost at depth. In contrast, shallower events resulting from freeze-thaw processes and increased active layer thickness are expected only during the warm season. With its occurrence at a likely warm permafrost area and the timing in December, the Crammont detachment fits into this broader picture. The heavy fracturing of the rock face (dense, large clefts) enhances water circulation, which may additionally have contributed to heat transport to deeper areas by advection. Observation of water seeping in the Crammont scar during the days following the collapse supports this.

\section{Re-analysis of the rock-avalanche runout}

In spite of its volume well below the threshold of $1 \times 10^{6} \mathrm{~m}^{3}$, which is commonly considered as minimum for being classified as a Sturzstrom (Hsü, 1975), the Crammont rock avalanche experienced high mobility. In addition to the steep relief and the dynamic rock mass disintegration, the enhanced mobility results from: (i) the lower friction at the interface between rock debris and snow; (ii) the incorporation of snow by the rock avalanche, that leads to saturation of the moving mass (Huggel et al., 2005); and (iii) the channelization by moraines on the plateau and torrent gullies, that has a funnelling effect by preventing lateral spreading. In different areas, erosion marks at the ground surface (soil pulled out, striae on boulders) or geometry of the deposit (stripes) indicate the direction of the moving mass, controlled by the moraines.

The runout of the Crammmont landslide was backanalyzed with DAN3D (McDougall and Hungr, 2004), a model based on the "equivalent fluid" approach, as defined by Hungr (1995). DAN3D is a relatively simple twodimensional dynamic model, controlled by a small number of adjustable parameters, which allows a simulation of the event's flow distance, velocity and distribution of deposits. Two grid files, describing the initial elevation of the sliding surface and the initial depth of the failure source volume, respectively, were provided as input to the model. Two different rheologies were combined to describe the landslide flow: a frictional model was used in the proximal path and a Voellmy rheology in the distal path, in order to simulate the effect of the snow in increasing the landslide mobility (Voellmy, 1955). The transition between the frictional and Voellmy models was placed at the base of the scree slope. Taking into account the presence of snow, a bulk friction angle of $30^{\circ}$ was adopted for the frictional model. The two Voellmy resistance parameters were adjusted by trial and error to achieve the best fit with the observed extension of the rock-avalanche deposit, considering also some published values from comparable case studies (Hungr and Evans, 1996; McDougall et al., 2006; Sosio et al., 2008). Values of friction coefficient $f=0.17$ (dimensionless) and turbulent coefficient $\xi=1000 \mathrm{~m} \mathrm{~s}^{-2}$ produced the best results. The first simulation gave good agreement in terms of flow distance but the results at the base of the scree slope were not consistent with the observed deposit thickness and distribution.

A two-phase simulation was then carried out, with two separate sliding volumes of $370000 \mathrm{~m}^{3}$ and $200000 \mathrm{~m}^{3}$, respectively, released in sequence. The resistance parameters previously specified were adopted for the first event. For the second event, the bulk friction angle was increased to $37^{\circ}$, based on the assumption that the snow on the talus slope had been removed during the first event. In order to simulate the topographic changes due to the first event, a slice of about $200000 \mathrm{~m}^{3}$ was subtracted from the original detachment area by simply translating upwards the original sliding surface. The topography of the second event was obtained by adding the first deposit to the original topography. Results show a better fit on the scree slope, with a deposit similar to that observed in the field (Fig. 13).

The large accumulation of rock debris and snow on the gentler bottom slope of the scar (Fig. 7), estimated to be ca. $100000 \mathrm{~m}^{3}$, has supplied the deposit remaining on the scree slope until the summer of 2009, when the sliding surface appeared nearly clean. Thus, modelling and observations suggest a two-phase event: (i) the 24 December rock avalanche, that involved the bulk collapsed material and reached the Doire River; and (ii) a continuous process of debris sliding and toppling from the scar during the following seven months (Fig. 14). This simulation of the second phase includes the assumption that a large volume of rock, left in the source area by the first phase, mobilized subsequently as a single second detachment some time between 24 December 2008 and the late spring of the following year. In fact, we have no evidence that such a large detachment occurred. More likely, the second phase of the instability consisted of a large number of smaller detachments, which gradually built up the thick deposits on the scree in the vicinity of the toe of the slope. In order to conduct a dynamic analysis of such a gradual process, it would be necessary to set up a number of models with small source volumes. However, since rockfalls or 

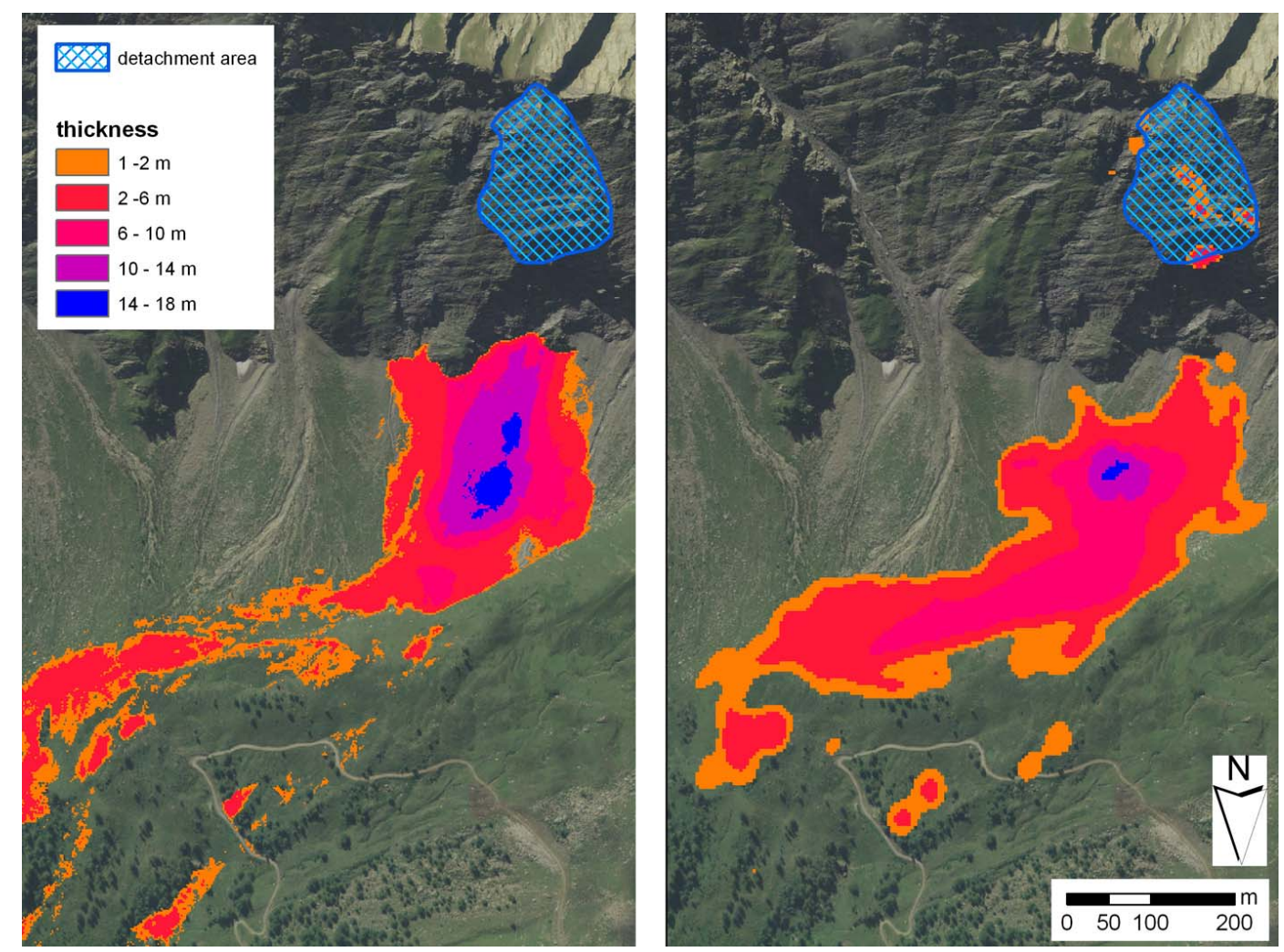

Fig. 13. Comparison between measured (left) and computed by DAN3D (right) rock-avalanche deposit thickness on the scree slope and the plateau.

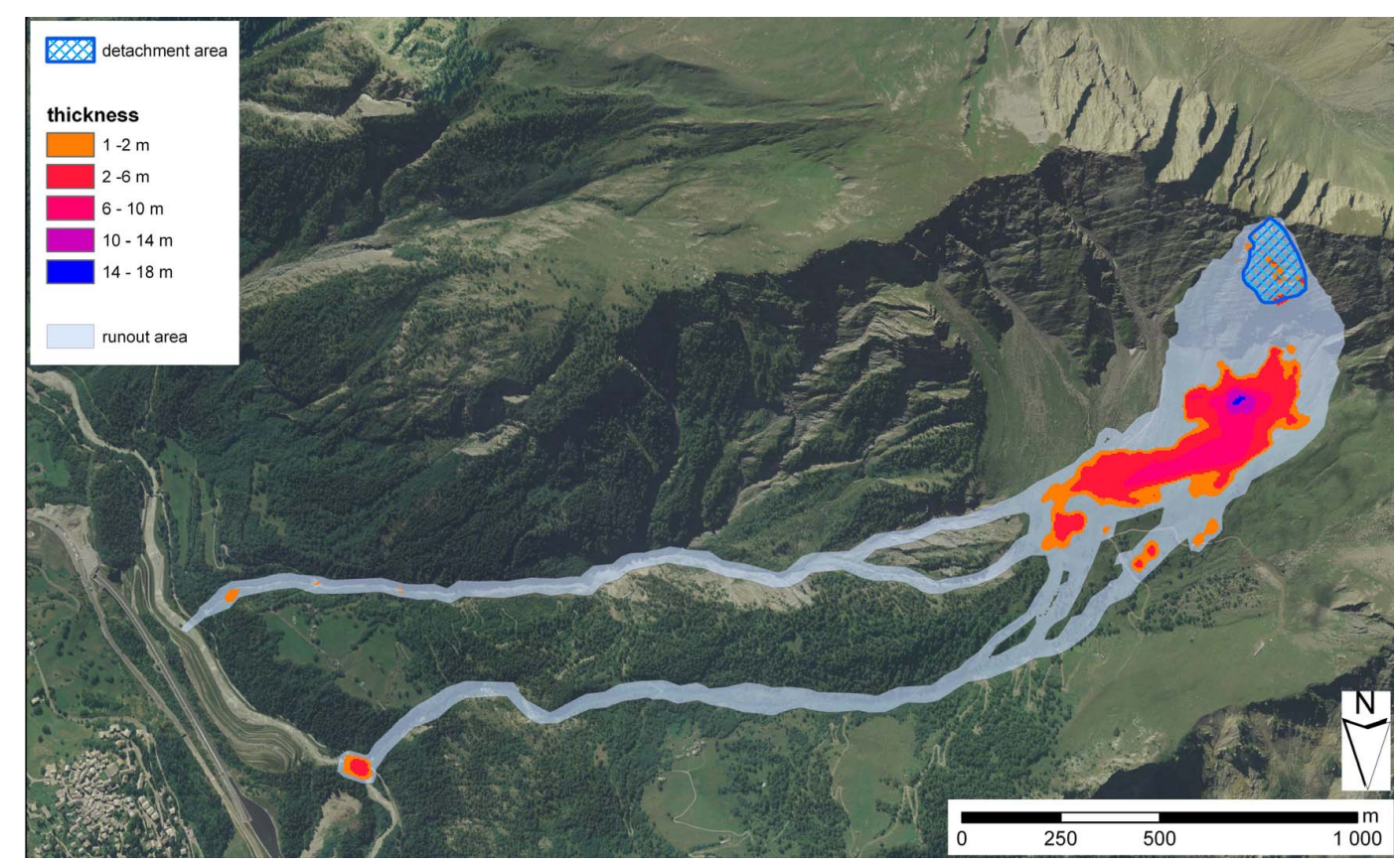

Fig. 14. Extension of the runout path and thicknesses of the accumulation computed by DAN3D considering a two-phase event. Compare with observed runout path on Fig. 6 . 
slides originating from the source area and depositing on the snow-free scree slope are likely dry and frictional in character, their deposit distribution is relatively independent of source volume, at least in terms of the displacement of the centre of gravity. Therefore, an analysis of a single detachment, as conducted here for Stage 2, produces approximately the same deposit as would be produced by the analysis of multiple smaller detachments. This is of course a gross approximation, but, in the absence of more detailed record of the slope activity during the winter, it is probably not constructive to attempt a more refined analysis. The important conclusion is that the high mobility of the 24 December 2008 event was caused by the mobilizing role of the snow cover, while the subsequent activity was more in line with normal dry rock slide behaviour.

\section{Conclusions}

1. A small rock avalanche, the 2008 Crammont event, is one of the major recent landslides in the Alps. Its slightly low apparent travel angle - especially considering its relative small volume $\left(0.5 \mathrm{Mm}^{3}\right)$ - results from its channelization and the incorporation of snow. This should draw our attention to the importance of local conditions (e.g. snow cover, topography) in the consideration of this hazard in the context of risk management.

2. A schematic model of rock temperature distribution in the Crammont ridge suggests that warm permafrost may be present in the north face at the elevation range of the scar. Climate warming since the termination of the Little Ice Age and especially in the past one or two decades likely degraded it, and heat advection by water circulation could have recently affected the rock mass at depth.

3. A two-phase back-analysis of the motion of the Crammont rock avalanche confirms the important role of snow in increasing its mobility. Agreement between simulated and observed trajectories of the sliding mass suggests that the velocities calculated by DAN3D are consistent with the real ones. Modelling is seen to contribute towards better understanding of the dynamics of the event, especially its two phases.

4. Occurring in a densely inhabited area of the Alps, close to one of the main international roads crossing the Alps, the Crammont rock avalanche emphasizes how this highly destructive process can place populations at risk, even at a considerable distance from the slope failure site. In the context of present global warming and further warming predicted for the 21 st century, permafrost degradation should accelerate, and more frequent rock avalanches could be triggered.
Acknowledgements. The authors thank M. Ravello, E. Zerga, G. Grange and the Fondazione Montagna sicura (Courmayeur) for information and photos, D. Cat-Berro and L. Mercalli (Società Meteorologica Italiana) for processing the Grand-Saint-Bernard pass data, F. Villa (Imageo) for preparation and simulations with DAN3D, and the two reviewers, T. Davies and C. Prager, for detailed and helpful comments that significantly improved the manuscript.

Edited by: T. Glade

Reviewed by: T. Davies and C. Prager

\section{References}

Antoine, P.: Le domaine pennique externe entre Bourg-St-Maurice (Savoie) et la frontière italo-suisse (Bilan des connaissances actuelles sur ce secteur de la zone des Brèches de Tarentaise), Géologie Alpine, 48, 5-40, 1972.

Auer, I., Böhm, R., Jurkovic, A., Lipa, W., Orlik, A., Potzmann, R., Schöner, W., Ungersböck, M., Matulla, C., Briffa, K., Jones, P.D., Efthymiadis, D., Brunetti, M., Nanni, T., Maugeri, M., Mercalli, L., Mestre, O., Moisselin, J., Begert, M., MüllerWestermeier, G., Kveton, V., Bochnicek, O., Stastny, P., Lapin, M., Szalai, S., Szentimrey, T., Cegnar, T., Dolinar, M., GajicCapka, M., Zaninovic, K., Majstorovic, Z., and Nieplova, E.: HISTALP - historical instrumental climatological surface time series of the Greater Alpine Region, Int. J. Climatol., 27, 17-46, 2007.

Ballantyne, C. K.: Paraglacial geomorphology, Quaternary Sci. Rev., 21, 1935-2017, 2002.

Broccolato, M., Martelli, D. C. G., and Tamburini, A.: Il rilievo geomeccanico di pareti rocciose instabili difficilmente accessibili mediante impiego di laser scanner terrestre. Applicazione al caso di Ozein (Valle di Cogne, Aosta), Geoingegneria Ambientale e Mineraria, 119, 39-46, 2006.

Coutterand, S. and Buoncristiani, J.-F.: Paléogéographie du dernier maximum glaciaire du Pléistocène récent dans la région du massif du Mont Blanc, Quaternaire, 17, 35-43, 2006.

Deline, P.: Recent Brenva rock avalanches (Valley of Aosta): new chapter in an old story?, Geogr. Fis. Din. Quat., Supplemento 5, 55-63, 2001.

Deline, P.: Interactions between rock avalanches and glaciers in the Mont Blanc massif during the late Holocene, Quaternary Sci. Rev., 28, 1070-1083, 2009.

Deline, P., Kirkbride, M. P., Ravanel, L., and Ravello, M.: The Tré-la-Tête rockfall onto the glacier de la Lex Blanche (Mont Blanc massif, Italy) in September 2008, Geogr. Fis. Din. Quat., 31, 251-254, 2008.

Evans, S. G. and Clague, J. J.: Catastrophic rock avalanches in glacial environments, in: Proceedings of the 5th International Symposium on Landslides, Balkema, Rotterdam, 2, 1153-1158, 1988.

Fischer, L., Kääb, A., Huggel, C., and Noetzli, J.: Geology, glacier retreat and permafrost degradation as controlling factors of slope instabilities in a high-mountain rock wall: the Monte Rosa east face, Nat. Hazards Earth Syst. Sci., 6, 761-772, doi:10.5194/nhess-6-761-2006, 2006.

Fischer, L., Purves, R., Huggel, C., Noetzli, J., and Haeberli, W.: On the influence of topographic, geological and cryospheric factors 
on rock avalanches and rockfalls in high-mountain areas, NNat. Hazards Earth Syst. Sci., in review, 2011.

Giardino, M., Borgogno Mondino, E., and Perotti, L.: Geomatics application for geological and geomorphological mapping and landslide hazard evaluation: case studies in the Italian NW-Alps, in: Proceedings of the 31st Symposium on Remote Sensing of Environment, Saint Petersburg (CSI), unpaginated CD-ROM, 4 pp., 2005.

Gruber, S. and Haeberli, W.: Permafrost in steep bedrock slopes and its temperature-related destabilization following climate change, J. Geophys. Res., 112, F02S18, doi:10.1029/2006JF000547, 2007.

Hasler, A.: Thermal conditions and kinematics of steep bedrock permafrost, PhD Thesis, University of Zurich, Zurich, 177 pp., 2011.

Hasler, A., Gruber, S., Font, M., and Dubois, A.: Advective heat transport in frozen rock clefts - conceptual model, laboratory experiments and numerical simulation, Permafrost Periglac., in press, 2011.

Hasler, A., Gruber, S., and Haeberli, W.: Temperature variability and thermal offset in steep alpine rock and ice faces, The Cryosphere Discuss., 5, 721-753, doi:10.5194/tcd-5-721-2011, 2011.

Hoek, E., and Bray, J.W.: Rock Slope Engineering, Institution of Mining and Metallurgy, pp. 360, 1981.

Hsü, K. J.: Catastrophic debris streams (sturzstroms) generated by rockfalls, Geol. Soc. Am. Bull., 86, 129-140, 1975.

Huggel, C., Zgraggen-Oswald, S., Haeberli, W., Kääb, A., Polkvoj, A., Galushkin, I., and Evans, S. G.: The 2002 rock/ice avalanche at Kolka/Karmadon, Russian Caucasus: assessment of extraordinary avalanche formation and mobility, and application of QuickBird satellite imagery, Nat. Hazards Earth Syst. Sci., 5, 173-187, doi:10.5194/nhess-5-173-2005, 2005.

Hungr, O.: A model for the runout analysis of rapid flow slides, debris flows, and avalanches, Can. Geotech. J., 32, 610-623, 1995.

Hungr, O. and Evans, S. G.: Rock avalanche runout prediction using a dynamic model, in: Procs., 7th. International Symposium on Landslides, edited by: Senneset, K., Trondheim, Norway, 1, 233-238, 1996.

Ivy-Ochs, S., Kerschner, H., Maisch, M., Christl, M., Kubik, P.W., and Schlüchter, C.: Latest Pleistocene and Holocene glacier variations in the European Alps, Quaternary Sci. Rev., 28, 21372149, 2009.

McDougall, S. and Hungr, O.: A model for the analysis of rapid landslide motion across three-dimensional terrain, Can. Geotech. J., 41, 1084-1097, 2004.

McDougall, S., Boultbee, N., Hungr, O., Stead, D., and Shwab, J. W.: The Zymoetz Rivel landslide, British Columbia, Canada: description and dynamic analysis of a rock slide-debris flow, Landslides, 3, 195-204, 2006.

Noetzli, J.: Modeling transient three-dimensional temperature fields in mountain permafrost, PhD Thesis, Department of Geography, University of Zurich, Zurich, Switzerland, 150 pp., 2008.
Noetzli, J. and Gruber, S.: Transient thermal effects in Alpine permafrost, The Cryosphere, 3, 85-99, doi:10.5194/tc-3-85-2009, 2009.

Noetzli, J., Hilbich, C., Hauck, C., Hoelzle, M., and Gruber, S.: Comparison of simulated $2 \mathrm{D}$ temperature profiles with timelapse electrical resistivity data at the Schilthorn crest, Switzerland, in: Proceedings of the 9th International Conference on Permafrost, Fairbanks, USA, 29 June-3 July 2008, 1293-1298, 2008.

Noetzli, J., Gruber, S., and von Poschinger, A.: Modellierung und Messung von Permafrosttemperaturen im Gipfelgrat der Zugspitze, Deutschland, Geographica Helvetica, 2, 113-123, 2010.

Orombelli, G. and Porter, S. C.: Il rischio di frane nelle Alpi, Le Scienze, 156, 68-79, 1981.

Pogliotti, P.: Influence of snow cover on MAGST over complex morphologies in mountain permafrost regione, $\mathrm{PhD}$ Thesis, University of Torino, Torino, 79 pp., 2011.

Porter, S. C. and Orombelli, G.: Late-glacial ice advances in the western Italian Alps, Boreas, 11, 125-140, 1982.

Ravanel, L. and Deline, P.: La face ouest des Drus (massif du Mont-Blanc) : évolution de l'instabilité d'une paroi rocheuse dans la haute montagne alpine depuis la fin du petit âge glaciaire, Géomorphologie, 4, 261-272, 2008.

Ravanel, L. and Deline, P.: Climate influence on rockfalls in highAlpine steep rockwalls: The North side of the Aiguilles de Chamonix (Mont Blanc massif) since the end of the "Little Ice Age", Holocene, 21, 357-365, doi:10.1177/0959683610374887, 2010.

Schneider, D.: On Characteristics and Flow Dynamics of Large Rapid Mass Movements in Glacial Environments, PhD Thesis, University of Zurich, Zurich, 261 pp., 2011.

Sosio, R., Crosta, G. B., and Hungr, O.: Complete dynamic model calibration for the Thurwieser rock avalanche (Italian Central Alps), Eng. Geol., 100, 11-26, 2008.

Suter, S.: Cold firn and ice in the Monte Rosa and Mont Blanc areas: spatial occurrence, surface energy balance and climatic evidence, $\mathrm{PhD}$ thesis, Versuchsanstalt für Wasserbau, Hydrologie und Glaziologie, ETH Zurich, Zurich, Switzerland, 188 pp., 2002.

Voellmy, A.: Über die Zerstörungskraft von Lawinen, Schweizerische Bauzeitung, 73, 159-162, 1955.

Wanner, H., Beer, J., Butikofer, J., Crowley, T. J., Cubasch, U., Fluckiger, J., Goosse, H., Grosjean, M., Joos, F., Kaplan, J. O., Kuttel, M., Muller, S. A., Prentice, I. C., Solomina, O., Stocker, T. F., Tarasov, P., Wagner, M., and Widmann, M.: Mid-to Late Holocene climate change: an overview, Quaternary Sci. Rev., 27, 1791-1828, 2008.

Zemp, M., Paul, F., Hoelzle, M., and Haeberli, W.: Glacier fluctuations in the European Alps 1850-2000: an overview and spatiotemporal analysis of available data, in: The darkening peaks: glacial retreat in scientific and social context, edited by: Orlove, B., Wiegandt, E., and Luckman, B., University of California Press, Berkeley, USA, 152-167, 2007. 